\title{
What is Social Informatics from an International Perspective?
}

\author{
Vasja Vehovar ${ }^{1}$ (D), Zdenek Smutny ${ }^{2}$ (D), Alice R. Robbin ${ }^{3}$ \\ ${ }^{1}$ Centre for Social Informatics, Faculty of Social Sciences, University of Ljubljana, Kardeljeva pl. 5, 1000 Ljubljana, Slovenia \\ ${ }^{2}$ Faculty of Informatics and Statistics, Prague University of Economics and Business, W. Churchill Sq. 1938/4, 13067 Prague, Czech Republic \\ ${ }^{3}$ Luddy School of Informatics, Computing, and Engineering, Indiana University, Bloomington, 700 N. Woodlawn Avenue, \\ Bloomington, IN 47408, USA
}

Corresponding author: Zdenek Smutny (zdenek.smutny@vse.cz)

\begin{abstract}
This editorial aims to summarise the special issue entitled "Perspectives of Social Informatics" that builds on the current international view of social informatics. The special issue consists of eight scientific articles and one book review.
\end{abstract}

\section{Keywords}

Social informatics; Socioinformatics; Sozioinformatik; Arkady Ursul; Russia; Germany; Japan; Slovenia; Czech Republic; Slovak Republic.

We are pleased to present a special issue of Acta Informatica Pragensia entitled "Perspectives of Social Informatics" after two years of preparatory and editorial work. This issue presents various regional perspectives of social informatics communities on the nature of this discipline, including relevant empirical research. The differences between the regional and international views of social informatics can be illustrated with examples of various meanings of the term social informatics by researchers and academics in different regions of the world.

This issue builds on an international view of social informatics presented by Smutny and Vehovar (2020), which goes beyond the traditional regional views of seven social informatics schools (North American, German, Russian, Norwegian, Japanese, Slovenian, United Kingdom). As such, the aim of this special issue is to enrich the broad international discourse of social informatics with various perspectives of social informaticians from around the world. In this context, we rely on the definition of social informatics in a broad international understanding presented by Smutny and Vehovar (2020, p. 537): 
Social informatics can be broadly defined as a research field that focuses on the research of sociotechnical interactions at different levels in connection with the development of the information society, including the social aspects of computerization and informatization, which can be structured into three main areas: interactions between ICT and humans, ICT applications in the social sciences, and ICT applications as a social sciences research tool.

This definition enriches the initial and prevailing definition offered by Kling et al. $(2005, \mathrm{p}$. 6) from the US. In addition to current general social informatics concepts, including the dominant one from 1996 (Kling, 2007) that continues to evolve (see Fichman et al., 2015), some specific concepts of social informatics have also appeared. A typical example is a new concept of social informatics that is "focused on the application of information technologies to capture and apply social data in conjunction with health data to advance individual and population health" (Pantell et al., 2020). In response, Shachak (2021) argues that

social informatics is a term already reserved for a different area of research, with a definition and research tradition of its own, and on which there are several books and articles, and even a Wikipedia entry. Many areas in biomedical informatics research are closely related to and are influenced heavily by social informatics (as defined previously) concepts.

Despite the above arguments, Pantell et al. (2021) still defend their new term social informatics and its definition. They argue that this term is not known from the point of view of researchers in health or (bio)medical informatics. They further argue that there are only six articles in their primary database PubMed that employ this term (regardless of the number of papers in databases such as Web of Science or Scopus). According to them, it is therefore entirely relevant to introduce a new discipline subsumed under health informatics, which will bring a new meaning to the term social informatics in the North American region. They also welcome a possible overlap with the older concept of Kling and his followers.

This exchange of views between Pantell et al. (2021) and Shachak (2021) is illustrative. The concept of social informatics presented by Pantell et al. resembles specifics of the German social informatics school (the area called Sozialinformatik). In both views, an international perspective that offers bridges to a mutual understanding is very useful to maintain as a minimal common denominator.

In preparation of this special issue, in mid-2020, we directly invited selected academics and researchers around the world associated with a particular school of social informatics and also published a Call for Special Issue (Vehovar et al., 2020) for other academics and researchers who had addressed the study of social informatics. In addition to submitted manuscripts from around the world, we also appreciated the words of support for our efforts to promote an international view of social informatics, e.g., from Pnina Fichman, who is the current director of the Rob Kling Center for Social Informatics at Indiana University Bloomington.

The peer-reviewed articles in our special issue can be organized into empirically or design-oriented and review articles. We also received one book review. Therefore, we would like to briefly introduce each of the nine published articles. We very much appreciate the introduction of the Russian social informatics school in two review articles. The first article, Social Informatics: 30 Years of Development of Russian Scientific School, is a personal retrospective of the development and focus of social informatics from the point of view of its important representative, Konstantin Konstantinovich Kolin [Константин Константинович Колин] (born 1935). The second review article, The Russian Concept of Social Informatics in Light of Information Technology Innovation: A Systematic Review, presents current phenomena and areas of interest conducted by social informatics by Russian academic authors.

German view of social informatics (Sozioinformatik) is provided by the third review article The Praxeological Research Programme of Socio-Informatics - the Siegen School. The article presents the praxeologically grounded research program developed at the University of Siegen and the German 
International Institute for Socio-Informatics. The authors present a methodological framework, "Grounded Design," that guides and integrates a variety of different engagements in practice which they call Design Case Studies. The last review article, Towards Re-Decentralized Future of the Web: Privacy, Security and Technology Development, addresses the new expansion of decentralized technologies that are currently transforming the information society. The emphasis in the article is mainly on current trends of the so-called re-decentralized Web.

Empirically or design-oriented articles follow. Social Informatics Experience: A Case Study on Learning and Teaching Sociological Basics in a Technical Context presents an approach and experience with learning and teaching social informatics (Sozioinformatik) topics at Furtwangen University, a university of applied sciences in Germany. Czech and Slovak Educators' Online Teaching Experience: A Covid-19 Case Study deals with the rapid transition to technologies enabling full online teaching in connection with the restrictions of the COVID-19 pandemic from the perspective of teachers. Hateful and Other Negative Communication in Online Commenting Environments: Content, Structure and Targets introduces the concept of socially unacceptable discourse, which appears at the intersection of society and new communication technologies. The concept serves as the basis for an empirical study that evaluated online comments scraped from Facebook pages of the three most-visited Slovenian news outlets. Japanese authors article, Discovery of Points of Interest with Different Granularities for Tour Recommendation Using a City Adaptive Clustering Framework, describes the design of a tourist recommendation system (as a part of a navigation system) to improve experience when traveling through points of interest.

In addition to these peer-reviewed articles, readers will also find a book review: Sozioinformatik - Von Menschen \& Computern ... und Bibern [Social Informatics: About People \& Computers ... and Beavers].

In our continuing research of the conceptual basis of social informatics in the world, we also came across probably the first use of the English term social informatics. This is Hawgood's (1973) article. The British author refers to the French concept of informatics established in 1966, which understands informatics as a broad computer-oriented area (Mounier-Kuhn \& Pégny, 2016; Smutny, 2020, pp. 48-54). On the other hand, in 1973, there was no computer-oriented informatics in the US, because there were well-established computer-oriented disciplines as computer science, computer engineering, library and information science, or information systems (mainly in business schools). All these disciplines in the US can be subordinated to the French concept of informatics from the 1960s in Western Europe. Work conducted by researchers in the United Kingdom represents a melting pot of European and US perspectives, which are reflected in Hawgood's article, so it is appropriate to present the whole context of the use of the term social informatics in this article.

Hawgood (1973) refers to the newly established area of information systems according to the ACM Curriculum from 1972 in the US. However, he presents these ideas in the context of European informatics. Hawgood employed the term social informatics for education focused on the social aspects of computers in Western Europe that should be very similar to new area of information systems in the US. Hawgood used the notion of social informatics to emphasize that informatics has not only a technological focus of a computer-based curriculum but also a social focus. He wanted to make a clear distinction between technologically- and socially-oriented education in a new field called informatics (the French concept of computer-oriented fields) that came to the UK from France in the late 1960s. Both views should be balanced, i.e., taking into account not only the technological view as was common in Western Europe at the time; and on that occasion he referred to a perspective of the socio-technical tradition of research in the UK from the 1950s. One reference is also to Enid Mumford's (1971) work. It is undoubtedly an interesting view from that time.

At the end of this editorial, we would like to remember Arkady Dmitrievich Ursul [Аркадий Дмитриевич Урсул] (1936-2020), an important (post)-Soviet philosopher (born in the former Ukrainian Soviet Socialist Republic, USSR), founder of the current school of social informatics in Russia. He is best 
known in the countries of the former Eastern Bloc because his books were translated into a number of these languages. In addition to social informatics, his main areas of academic interest included noospherology, the philosophy of information and information culturology. These areas and their ideas are also imprinted in social informatics in the Russian school. His academic life is summarized in detail in Kolin's (2016) article. We honour his memory.

\section{References}

Fichman, P., Sanfilippo, M. R., \& Rosenbaum, H. (2015). Social Informatics Evolving. Morgan \& Claypool.

Hawgood, J. (1973). Informatics is a Social Science. Personnel Review, 2(2), 82-87. https://doi.org/10.1108/eb055233

Kling, R., Rosenbaum, H., \& Sawyer, S. (2005). Understanding and Communicating Social Informatics: A Framework for Studying and Teaching the Human Contexts of Information and Communication Technologies. Information Today.

Kling, R. (2007). What Is Social Informatics and Why Does It Matter? The Information Society, 23(4), $205-220$. https://doi.org/10.1080/01972240701441556

Kolin, K. K. (2016). Outstanding Scientist of Our Time: to the 80th Anniversary of Academician A.D. Ursul. Journal of Siberian Federal University. Humanities \& Social Sciences, 9(9), 2194-2201. https://doi.org/10.17516/1997-1370-2016-9-9-2194$\underline{2201}$

Mounier-Kuhn P-É., \& Pégny M. (2016). AFCAL and the Emergence of Computer Science in France: 1957-1967. In A. Beckmann, L. Bienvenu, \& N. Jonoska (Eds.), Pursuit of the Universal (pp. 170-181). Springer. https://doi.org/10.1007/978-3-319-40189-8 18

Mumford, E. (1971). Systems Design for People. National Computing Centre.

Pantell, M. S., Adler-Milstein, J., Wang, M. D., Prather, A. A., Adler, N. E., \& Gottlieb, L. M. (2020). A call for social informatics. Journal of the American Medical Informatics Association, 27(11), 1798-1801. https://doi.org/10.1093/jamia/ocaa175

Pantell, M. S., Adler-Milstein, J., Wang, M. D., Prather, A. A., Adler, N. E., \& Gottlieb, L. M. (2021). A reply to Shachak. Journal of the American Medical Informatics Association, 28(6), 1358-1359. https://doi.org/10.1093/jamia/ocab022

Shachak, A. (2021). Social informatics is a poor choice of term: A response to Pantell et al. Journal of the American Medical Informatics Association, 28(6), 1356-1357. https://doi.org/10.1093/jamia/ocab021

Smutny, Z. (2020). Diskurz sociální informatiky: Metodologická východiska, myšlenkové školy a tematická konceptualizace [Discourse of Social Informatics: Methodological Backgrounds, Schools of Thought and Thematic Conceptualization]. Professional Publishing.

Smutny, Z., \& Vehovar, V. (2020). Social informatics research: Schools of thought, methodological basis, and thematic conceptualization. Journal of the Association for Information Science and Technology, 71(5), 529-539. https://doi.org/https://doi.org/10.1002/asi.24280

Vehovar, V., Smutny, Z., \& Robbin, A. R. (2020). Call for Special Issue Papers: Perspectives of Social Informatics. Acta Informatica Pragensia, 9(2), 224-227. https://doi.org/10.18267/j.aip.140

Acta Informatica Pragensia is published by Prague University of Economics and Business, Czech Republic.

ISSN: $1805-4951$ 